\title{
Spreading Fake News in the Virtual Realm in Bangladesh: Assessment of Impact
}

By Sharifa Umma Shirina \& Md. Tabiur Rahman Prodhan

University of Barishal

Abstract- Fake news is 'false, often sensational, information disseminated under the guise of news reporting.' The upsurge of technological advancement, especially social media, has paved the way for spreading fake news. The virtual realm spurs fake news as per the speed of air. Nowadays, fake news has been one of the social problems in the world along with Bangladesh. Self-seeker groups use fake news as an 'atomic arsenal' to disseminate their popular rhetoric with supersonic speed for fulfilling male purposes. Fake news is usually rampant during any crisis, elections, and even in campaigns. The hoaxers and fakers exploit the opportunity of the wavering psychology of the social media users, and fake news becomes 'viral' on social media, Facebook. Recently Bangladesh has faced an acute crisis of spreading fake news during the 'Movement of Nirapod Sarak Chai, 'National election in December 2018' and very recent 'need child's head for Padma Bridge.' This study titled "Spreading Fake News in the Virtual Realm in Bangladesh: Assessment of Impact" seeks the reasons for spreading fake news and its' social impact in Bangladesh.

Keywords: fake news, rumor, social media, mob lynching, virtual real, viral, social movement.

GJHSS-A Classification: NLMC Code: 190399

Strictly as per the compliance and regulations of:

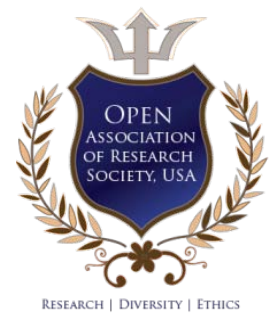

(C) 2020. Sharifa Umma Shirina \& Md. Tabiur Rahman Prodhan. This is a research/review paper, distributed under the terms of the Creative Commons Attribution-Noncommercial 3.0 Unported License http://creativecommons.org/licenses/by-nc/3.0/), permitting all non-commercial use, distribution, and reproduction in any medium, provided the original work is properly cited. 


\title{
Spreading Fake News in the Virtual Realm in Bangladesh: Assessment of Impact
}

\author{
Sharifa Umma Shirina ${ }^{\alpha} \&$ Md. Tabiur Rahman Prodhan ${ }^{\sigma}$
}

Abstract- Fake news is 'false, often sensational, information disseminated under the guise of news reporting.' The upsurge of technological advancement, especially social media, has paved the way for spreading fake news. The virtual realm spurs fake news as per the speed of air. Nowadays, fake news has been one of the social problems in the world along with Bangladesh. Self-seeker groups use fake news as an 'atomic arsenal' to disseminate their popular rhetoric with supersonic speed for fulfilling male purposes. Fake news is usually rampant during any crisis, elections, and even in campaigns. The hoaxers and fakers exploit the opportunity of the wavering psychology of the social media users, and fake news becomes 'viral' on social media, Facebook. Recently Bangladesh has faced an acute crisis of spreading fake news during the 'Movement of Nirapod Sarak Chai, 'National election in December 2018' and very recent 'need child's head for Padma Bridge.' This study titled 'Spreading Fake News in the Virtual Realm in Bangladesh: Assessment of Impact" seeks the reasons for spreading fake news and its' social impact in Bangladesh. This paper is based on secondary literature. The Rapid growth of online journalism, most of the online portals are run by unskilled, and less educated persons, lack of news sense, lack of national security act for controlling web portal, lack of ethical knowledge of journalism, lack of implementation of the law to punish criminals, mistrust on existing justice, mistrust on police who are detached from mass people, taking revenge on political rivals, derange social discipline, creating a chaotic environment, the suspicious mind of mass people, lack of knowledge and mass awareness are the main reasons of spreading fake news in Bangladesh.

Keywords: fake news, rumor, social media, mob lynching, virtual real, viral, social movement.

\section{INTRODUCTION}

Today, after more than a century of electric technology, we have extended our central nervous system itself in a global embrace, abolishing both space and time as far as our planet is concerned.

- Marshall McLuhan, Understanding Media, 1964.

- oday we live in such a world which is defined as a 'Global Village.' The term 'Global Village' was traced by communication scholar Marshal McLuhan and popularized by him. McLuhan's dream of a global village becomes true by inventing the internet.

Author a: Assistant Professor, Department of Mass Communication and Journalism, University of Barishal, Barishal, Bangladesh.

e-mail: sushirin.mcj.du@gmail.com

Author o: Assistant Professor, Department of Mass Communication and Journalism, Begum Rokeya University, Rangpur, Bangladesh. e-mail: tabiurbd@gmail.com
Modern technology and the internet are the key drivers, and the major force of global village. Hence the world is now in our grip like smartphone. The internet connects the world and makes the world like a village. Technology and the internet introduce us to a new world as well, which can be referred to as 'Virtual Realm.' Social media like Facebook, twitter, WhatsApp, youtube, and other new media, blogs, online news portals are the platform of the virtual realm. This new media creates an artificial world where we are living now. Specially Facebook and youtube contribute greatly to create this artificial but virtual realm. Among 7.7 billion (worldometers.info: 2019) world's population, over 4.39 billion people are active internet users, encompassing $57 \%$ of the global population. The internet users are increasing gradually. In Bangladesh, Internet users are retroactively increased at present. The total number of Internet subscribers has reached 98.136 million at the end of August 2019, where 91.348 million Internet users were in December 2018 (BTRC: 2019). But most of the internet users use the internet for using Facebook. As of June 2019, there are an estimated 2.4 billion monthly active Facebook users, among whom 1.6 billion daily active Facebook users worldwide (dustinstout.com: 19 October 2019). In Bangladesh, the number of social media users is 34 million. Among them, 33.713 million (96.04\%) is Facebook users, whereas 0.67 million (1.98\%) visit youtube. The majority of them are men $73.8 \%$. The young generation aged 18 to 24 is the largest group (15.6 million) of Facebook users (statista.com: 19 October 2019). Most of them are young adolescent college or university going students. Facebook is the highest and frequently visited new media in Bangladesh. On average, 10 minutes, 57 seconds are spent by the viewers of this site (alexa.com: 20 October 2019). As Facebook is a widely used social media in Bangladesh, it is used as a great platform for spreading fake news in Bangladesh. Facebook has a great impact on overpopulated countries like Bangladesh. Facebook is the most popular social network in Bangladesh. In Bangladesh, almost all internet users use Facebook regardless of age, gender, locality, or ethnic identity. Nowadays, Facebook becomes an integral part of daily activities. Alongside, Facebook is being used for social Communication, knowledge and experience sharing, and business purposes; for spreading fake news and rumors at supersonic speed towards mass people. 


\section{Fake News: Conceptual Clarity}

Fake information can be defined as the 'deliberate creation and sharing of information known to be false' (Wardle: 2017). Fake news is more dangerous to society. 'Fake news,' which, according to former US president Barack Obama, creates a 'dust cloud of nonsense,' has become one of the most popular 'sociopolitical topics' in the world right now, thanks to the rapidly growing social media presence across the cultures. Fake news is 'false, often sensational, information disseminated under the guise of news reporting' (Collins English Dictionary). Fake news is to be news articles that are intentionally and verifiably false and could mislead readers (Allcott and Gentzkow: 2017). So fake news can be defined as a news article or message which is published and propagated as false information regardless of meaning, and sometimes which has a motive behind it. The upsurge of technological advancement, especially social media, has paved the way for spreading fake news. The virtual realm spurs fake news as per the speed of air. Nowadays, fake news has been one of the major social problems in the world along with Bangladesh. But the idea of fake news isn't new something. The world faced the crisis of spreading fake news during World War 1. But today, self-seeker groups use fake news as an 'atomic arsenal' to disseminate their popular rhetoric with supersonic speed for fulfilling male purposes. Fake news is usually rampant during any crisis, elections, and even campaigns. The hoaxers and fakers exploit the opportunity of the wavering psychology of the social media users, and fake news becomes 'viral' on social media, Facebook. But society suffers much for spreading single fake news. Recently Bangladesh has faced several acute crisis of spreading fake news during the 'Movement of Nirapod Sarak Chai, 'National election in December 2018' and very recent 'need child's head for Padma Bridge.' Borhanudding, Bhola incident is also the worst example of spreading fake news in Bangladesh.

\section{ili. Purpose of the Study}

Social media has a direct impact on the society around the world including Bangladesh. But the influence of social media, especially Facebook, in Bangladesh, is severe as a densely populated country. New media and online journalism immensely arise worldwide due to the internet. Besides, Facebook, twitter, youtube, others new media like WhatsApp, messenger, and online news portals have also led to the proliferation and spreading of fake news. The main objective of this paper is to explore the social impacts of spreading fake news through the virtual realm and identify the reasons for spreading fake news in Bangladesh as well.

\section{Methodology}

This paper is based on secondary literature and data collected from different dailies, online sources, and research papers. Besides, it has been screened social media to observe how fast fake news gets spreading in the virtual realm during the different social crises. Some Facebook posts are also collected as data to see how people become distracted by the fake news and play a role in spreading fake news without knowing its' authenticity.

\section{Global Scenario of Fake News}

Spreading fake news is a problematic global phenomenon that becomes the cause of worry of global leaders. People are suffering a lot worldwide due to fake news. Even technological developed country like the USA also suffers much for spreading fake news. The people of the USA believe in fake news unknowingly and become disconcerted by fake news where the literacy is very high (100\%). This fake news are spreading through the virtual realm as people are habituated to digital media like online news portals, Facebook, Twitter, Linkedln, Instagram, and Youtube, which are free of cost. According to Pew Research Group (2017), roughly 93\% of people in the USA get their news online (either via mobile or desktop) circulated through social media, especially Facebook and youtube. Recent researches on the USA President Election 2016 show that most popular fake news stories were more widely shared on Facebook than on the other popular mainstream news media. In 2016, most discussed fake news stories in USA tended to favor Donald Trump over Hillary Clinton (Silverman: 2016). The alarming thing about spreading fake news is that many people who see or read fake news stories report that they believe them (Silverman \& Singer-Vine: 2016). Evidence shows that the consequence of fake news not only helps Trump to win but leads to the death of common people. In October 2017, a slightly distorted news titled headline "FBI Says Las Vegas Shooter Has Connection With Daesh Terror (ISIS) Group" about the Las Vegas massacre became viral on Google and Facebook, which killed at least 59 people and injured more than 500 people. This fake news was spread by Russian propaganda site Sputnik, the internet's largest news platform, which failed to manage spreading misinformation. Later, Sputnik removed this article and replaced it with a story making the opposite claim -"FBI Says Las Vegas Shooter Has No Connection With Daesh Terror (ISIS) Group" without acknowledging its original false story" (Kathleen Chaykowski: 2017). The global community worries about fake news as it is a growing concern. In 2019, Ipsos conducted a poll on fake news in Canada. The Ipsos poll for Global news reveals $90 \%$ of Canadians admit to falling for fake news (Connolly: 2019). Most of the 
Canadian (almost 71\%) worry about Fake news (Cain: 2019).

Asian countries have not been immune to the fake news phenomenon. As reported by Russel Goldman in New York Times (2016), a hoax story reported in December 2017 spread the threats of nuclear war between Pakistan and Israel. It caused panic in the streets of Pakistan (Nagi: 2019). A horrible scenario caused by fake news can be seen in India. Besides Facebook, WhatsApp contributed a lot to spreading fake news in India and made a massacre result. WhatsApp, which has more than 200 million users, the biggest market of the messaging application in India, has already made a huge mess in the country as at least 30 people fell victim to lynching due to the circulation 'fake news' through the WhatsApp since January last year. BBC's research finds that Indians are 'reluctant to share messages which they think may incite violence, but they feel duty-bound to share nationalistic messages.' 'Fake news stories regarding India's progress, Hindu power, and revival of lost Hindu glory are being shared widely without any attempt at factchecking,' said the BBC researchers (Islam: 2019; Prothom Alo English). There are more than 50 documented cases of mob violence triggered by misinformation spread over social media in India in the last two years. Many platforms, including Facebook, YouTube, and Sharechat, a vernacular language social media start-up and app, play a role (Roy: 2019). In 2018, India was shaken by a spate of mob killings sparked by a hoax about child kidnappers spread on WhatsApp. In just two months, 20 people have been murdered in mob lynching due to the spreading of rumor of child kidnapping but officials and social media platforms have so far been powerless to stop the violence. Many victims in other vigilante killings, such as those over child kidnapping rumors, are targeted because they are outsiders (AFP, New Delhi: 2018). The rumor of child kidnapping can't be stopped but continuing in India. On 22 August 2019, a mental challenge was pinned down on his stomach in Banda, Uttar Pradesh, suspecting him a child kidnapper. The rush of rumors of child- kidnapping and offline instances of violence over a six-week period found the police grappling for solution. Like Banda, Bundelkhand, Chhatarpur, Chitrakoot, and in many other districts of Uttar Pradesh, India, a roughly estimated over 100 incidents of mob violence due to child lifting rumors, in August alone in the state. According to data from IndiaSpend, there have been more than 33 cases of murder and over 99 cases of attacks triggered by rumors of child kidnapping between 2017-18 (Lahariya: 2019).

\section{Impact Of FAKE News in Bangladesh}

Bangladesh suffers much for fake news. Facebook is the most used and popular social media in
Bangladesh, and becomes a widely used tool for spreading fake news. Among the 163.6 million (2019) population of Bangladesh, almost 33.713 million people use Facebook and some have multiple Facebook IDs. Even some Facebook ID is opened only for the purpose of spreading fake news. The problem of spreading fake news is acute in Bangladesh during the crisis. Sometimes, a crisis moment has been created by spreading fake news through Facebook, which is the fastest medium to reach a maximum audience. Facebook has direct impact on our society. Even some Facebook centered movements have already occurred in Bangladesh indicating the direct impact of Facebook on our society. Such 'Ganojagoron Mancho' in 2013 and recently 'road safe movement' are the result of Facebook. Fake news has a seasonal outbreak too. Fake news is usually rampant during any crisis, elections, and even campaigns. The hoaxers and fakers exploit the opportunity of the wavering psychology of social media users (Islam: 2019; Prothom Alo English). Bangladeshi young generation who use Facebook is suffering from a viral virus. Fake news becomes viral with a supersonic speed and its' impact on society like an 'arsenal atomic bomb.' Some incidents happened for fake news has been illustrated to show the impact of fake news, which creates massacre and causes to death many innocent people.

\section{a) Borhanuddin, Bhola, 20 October 2019}

Very recently on 20 October 2019, a clash between villagers and police over an unverified Facebook post in Borhanuddin, Bhola. The clash is triggered by a Facebook post. The unwanted and unfortunate result of this clash is 4 people were killed and more than 200 others injured (20 October 2019; Prothom Alo English) including ten policemen (20 October 2019; bdnews24.com), and one house was torched and 12 more belongings of Hindu community were vandalized (21 October 2019; Daily Star).

A post from Facebook ID of Biplod Chandra Shuvo containing derogatory remarks about Allah and Prophet Muhammad (S) went viral on Facebook, triggering condemnation and protests. Hundreds of villagers gathered for a rally under the banner of 'Muslin Tawhidi Janata' in protest against the social media post and demand punishment of the youth, Biplob Chandra Shuvo, for allegedly hurting religious sentiments on Facebook. The situation went beyond the control of the police, and at one stage of the procession, police fired rubber bullets to disperse the crowd and resulted in 4 death and more than 200 wounded. But the man, Biplob Chandra Shuvo, claimed that his Facebook account was hacked and went to the police station to file a general dairy (GD) the previous night (20 October 2019; bdnews24.com). The hacker has not yet been identified, but the process is on (25 October 2019; Daily Star). In the past, rumors through Facebook posts led to 
incidents of attacks on minority communities. Such attacks took place in Ramu of Cox's Bazar in 2012, Ataikula in Pabna in 2013, Nasirnagar in Brahmanbaria in 2016, and Horkoli Thakurpara in Rangpur in 2017 (21 October 2019; Daily Star).

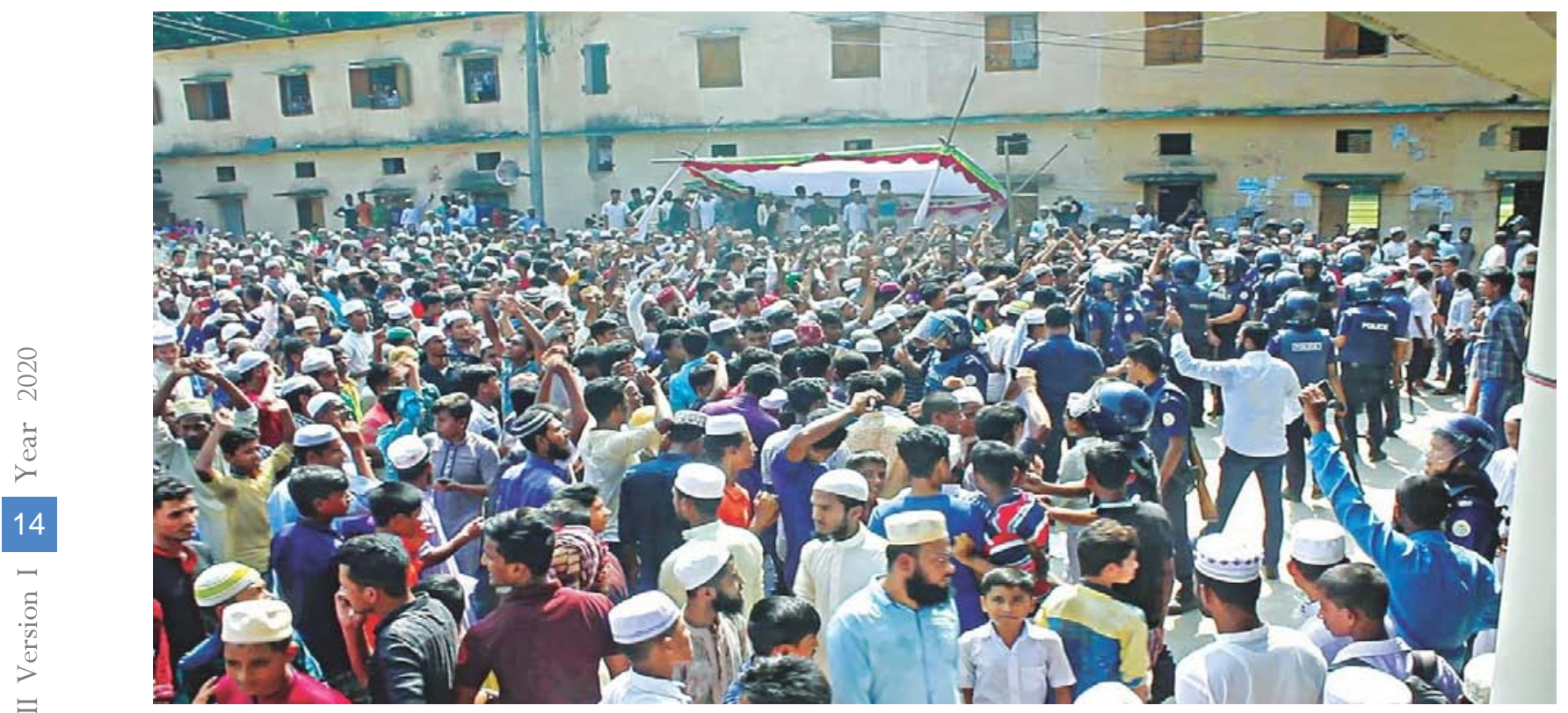

Figure 1: Visual representation of the impact of rumors on Facebook in Borhanudding, Bhola.

'Tawhidi Muslim Janata' activists, closely watched by riot police, gather for a rally in Bhola's Borhanuddin Upazila on October 20 2019. Star file photo

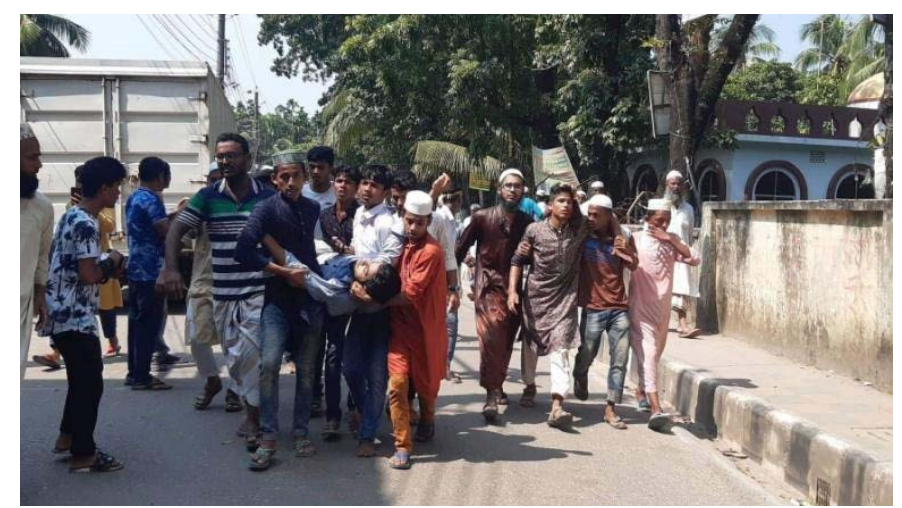

Locals carry an injured person after a clash between villagers and police over an unverified Facebook post in Borhanuddin Upazila of Bhola on Sunday, October 20, 2019. Photo: Dhaka Tribune.

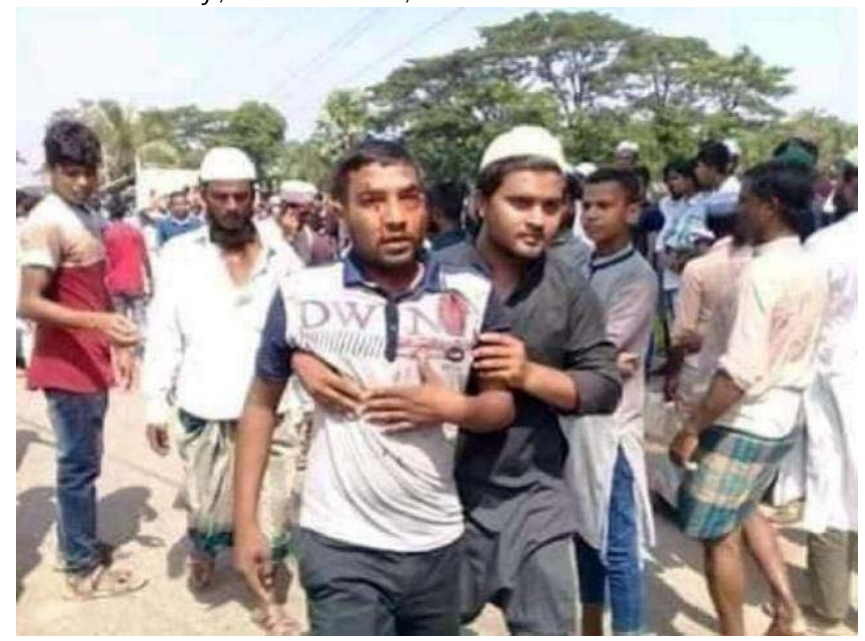


An injured person is being taken away. Photo: Prothom Alo.

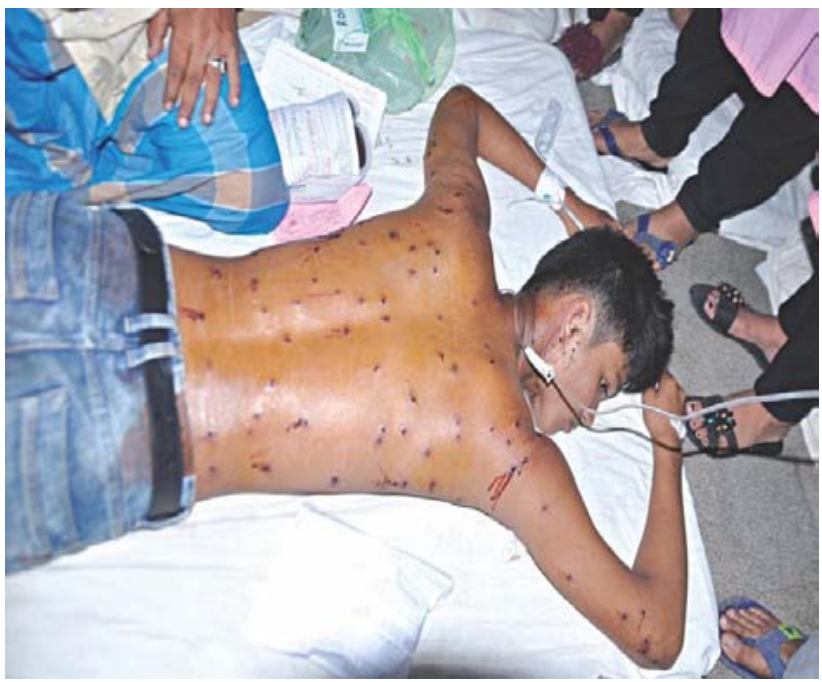

An activist with his back covered in shotgun-pellet wounds lying on a hospital bed following the clash with police. Photo: Daily Star.

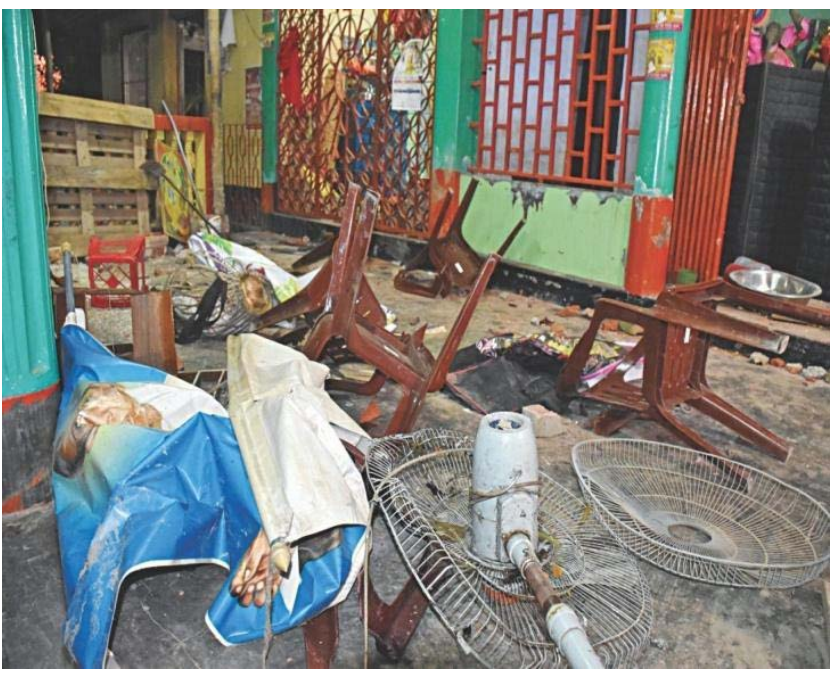

Pieces of broken furniture lie scattered on the floor of Sri Sri Gournitai Ashram in Bhola's Bhawalbari after the temple was attacked by religious zealots yesterday. Photo: Daily Star

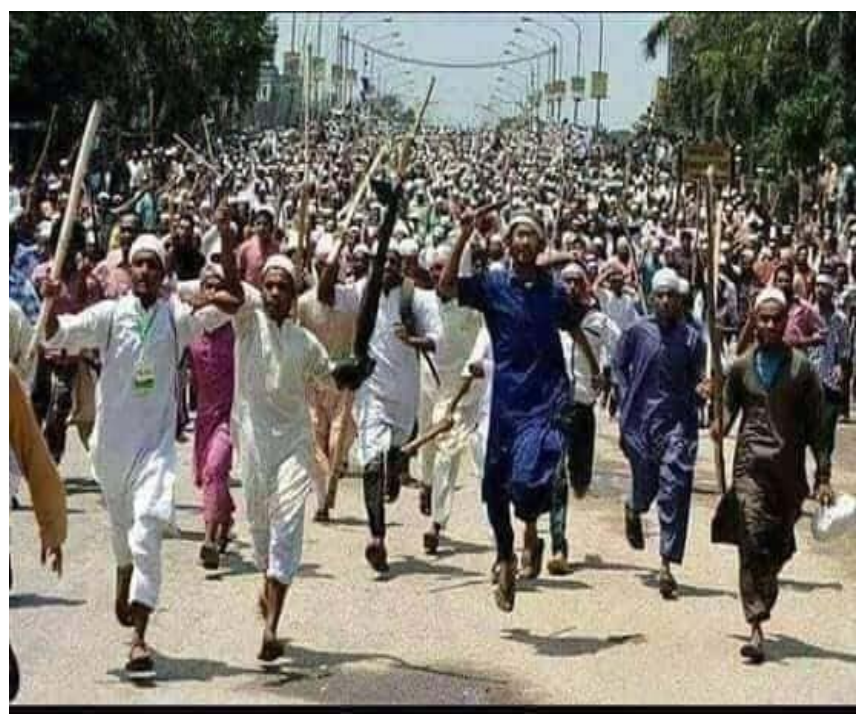


This picture went viral on Facebook as the situation of Borhanuddin, Bhola though it wasn't true, and was taken before in other incidents.

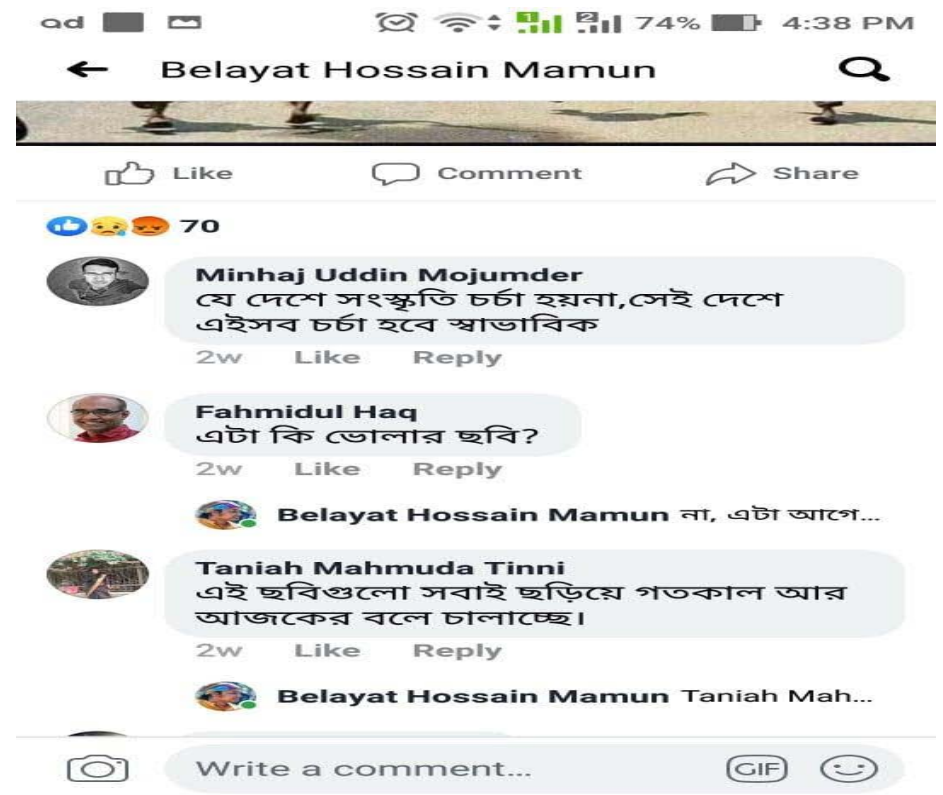

b) Rumors of child kidnapping for Padma Bridge

Bangladesh suddenly faced acute rumors of child kidnapping in the $2^{\text {nd }}$ half of July 2019. Social media especially Facebook is used as a rumor spreading machine in Bangladesh. Suddenly a rumor of child sacrifices being required for the completion of Padma Bridge, the largest \$3bn projects in Bangladesh spread on both social media (Facebook, online news portals) and offline across the country. This rumor sparked after a report circulated of a young man allegedly found carrying the severed head of a child in the northern district of Netrokona on 18 July 2019 (25 July 2019; theguardian.com).

Nine people have been killed in vigilante mob lynching in 9 several districts in Bangladesh sparked by rumors on the virtual realm (Facebook) of child kidnapping till 23 July 2019 (Shirin, 25 July 2019). More than 30 other people have been attacked in connection with rumors (25 July 2019; theguardian.com). Most of the victims were women, deaf, and even mentally challenged person who were outsider. Among the latest victims was a mother of two, Taslima Begum Renu, who was beaten to death in front of a Dhaka school on $20^{\text {th }}$ July 2019 by a mob that suspected her of being a child kidnapper. Even a deaf man was also beaten to death outside the capital that day while visiting his daughter suspected in the same rumor. At least 25 youtube channels, 60 Facebook pages, and ten websites accused of spreading the rumors have been shut down (25 July 2019; theguardian.com).

\section{c) Quota Reform Protests in April 2018}

Bangladesh has observed a massive protest of both public and private university students on existing quota reformation. Though this quota reform protest initiates from students of Dhaka University, a prominent public university of Bangladesh, it sparked across the countries all tertiary level of education institutes. This protest one of the longest but successful protests of university students has seen in recent past.

The protests continued sporadically in March and gained momentum in early April 2018 though protesters came under the banner of "Bangladesh Sadharon Chhatra Odhikar Sangrakkhon Parishad" midFebruary to organize peaceful demonstrations in favor of reforming the quota system. Both public and private university students, including college students, gathered in streets and blocked key intersections of Dhaka along with other parts of the country, bringing traffic to a grinding halt. The demands raised by protesters in Dhaka struck a chord with students and job seekers across Bangladesh. All students, who protest, across the country boycotted classes and expressed solidarity with the quota reform movement. Protesters declared a massive gathering in April and blocked the key Shahbag intersection in Dhaka for five hours. The protesters asked to government to reform the existing 56\% reserved quota to only $10 \%$ for expanding opportunities for candidates who don't have quota facilities (Raju \& Shovon: 2018).

But this anti-quota protest turned violent only after several rumors were spread in social media platform Facebook, it has emerged after massive gathering in 8 April, which had largely been peaceful until then (Raju \& Shovon: 2018).

The Dhaka Tribune, one of the leading online English newspapers in Bangladesh, found that much of the chaos and violence during the protests were fuelled by rumors on the social media. Several rumors, given 
following, shaped the quota reform movement turning into violence.

i. Around midnight on Sunday, April 8, a rumor spread that a rubber bullet fired by the police had hit one of the protesters in the scrotum. Another rumor misinformed people of the death of Abu Bakar Siddique, a protester who had been injured when a rubber bullet hit him on the left eyebrow. One of the movement's conveners also told a private TV channel that one of the protesters had been killed. This fake news was quickly picked up and went viral through different Facebook pages and prominent personalities posted without verifying that Siddique was shot dead by police during a clash. Facebook pages like 'Troll Du,' 'Quota Songskar Chai,' 'Zakir's BCS Specials,' 'Basher Kella' started posting news about Siddique's death early hours of April 9. But Siddique later went to a live Facebook video and posted a status clarifying that he was okay. Meanwhile, Dhaka Medical College Hospital's Dr. Alauddin told the Dhaka Tribune that on Sunday night, no one was admitted with a scrotum injury.

ii. Another rumor was spread by leaders of the Bangladesh Chhatra League, the ruling party's student front, that the protesters had vandalized the faculty of Fine Arts and torched the artwork that was supposed to be used in the Mongol Shobhajatra. But the Chhatra League later issued a statement condemning the alleged vandalism. Besides, Mir Arshadul Haque, the campus correspondent of a English daily, confirmed to Dhaka Tribune that vandalism is fake, and he was inside the Fine Arts Faculty at that time.

iii. Another report of the violence surfaced at mid-night around 2 am on 9 April when protesters surrounded the residence of the Dhaka University vicechancellor. A few people, who have yet not identified, attacked, vandalized, and looted the residence. Two cars of the vice-chancellor were also set fire while two other cars were vandalized. The news was served as that the protesters were behind this heinous vandalism, but demonstrators alleged that the attack on the residence was carried out by outsiders and still now they are not identified.

iv. There was another rumor early April 11 that Chhatra League's Kabi Sufia Kamal Hall unit President Iffat Jahan Isha had tortured a demonstrator and cut her tendon. It is claimed in the rumor that the leader didn't permit to take the demonstrator to the hospital even though she was bleeding. This rumor spread on Facebook at supersonic speed and incite the protesters along with commoners further. This rumor became trustworthy as the picture and video of wounded girl was posted on Facebook. Tension arises to the apex, and guardians of the students worried about their girls, and this rumor led both protesters and common people agitated. Later, the injured student, Morsheda, clarified in a Facebook video that she had herself injured her foot on broken glass when she kicked the window of Isha's room to rescue a screaming girl who was presumably being tortured there.

v. At around 3 am on 11 April's night, another post by Basher Kella claimed that a ruling party student front leader of Dhaka University's hall unit was assaulting general students. The page claimed that armed Chhatra League activists riding around 100 bikes were on the way TSC to attack the protesters.

vi. Another rumor that arise based on the Isha's cut off the tendon of a protester because Chhatra League activists had fired shots at students who tried to go towards the Kabi Sufiya Kamal Hall. But a protester dismissed this rumor.

vii. There were also few rumors about Chhatra League activists assaulting protesters at Mohsin Hall, a residence of students for Dhaka University. Still, the Dhaka Tribune correspondent couldn't find evidence to substantiate the allegation.

The government tried hard to tackle rumors. About 200 Facebook accounts have been listed in connection to a case filed over "spreading rumors" in the social media during the quota reform agitation in Dhaka (13 April 2018; Daily Star).

The important thing is that this massive student movement, led by students, was organized solely through social media i.e. Facebook alike movement had been seen 'Ganojagoron Mancho' in 2013 in Bangladesh. World has seen the massive power of social media, i.e., Facebook in these two different movements happened in Bangladesh and the Arab Spring in the Middle East in 2012. Later, another massive but peaceful and dynamic 'Road Safety Movement' led by school-going students been seen in Bangladesh organized through Facebook. Thus social media especially Facebook has a massive and direct influence on society in Bangladesh.

\section{d) Rumors spread during the 'Road Safety Movement'} through Facebook in July 2018

The world faces rumors during crisis moments. Hoaxers and fakers take the opportunity of the emergency period and exploit human psychology and create chaos in society. Especially political rivals grab the advantage of juncture when a country faces movement or war. Hence rumor spread at the highest speed to reach people during world war 1 and world war 2 and other war or crisis time. Bangladesh also suffered much in rumor during the freedom war in 1971. But in rumors get new life and way of spreading in such a way like the atomic bomb in this digital age. Facebook and online portals add a new dimension in spreading rumors and fake news. 
Recently rumor is the rampant speed the movement of 'Safe roads movement' in Bangladesh. Not only Bangladesh but the world has seen for the first time a new style of the movement named 'Road safety movement' or 'Safe roads movement.' This movement arises on the deaths of two students of Shaheed Ramiz Uddin Cantonment College at Kurmitola by road accident on Airport Road in Dhaka on $29^{\text {th }}$ July 2018 (3 August 2018; bdnews24.com). This road accident triggered widespread protests for justice and road safety measures solely led by school going kids and children. This 11 days long exceptional school-going students' movement was peaceful and last till 8 August. But few hoaxers tried to make this peaceful movement violent by spreading fake news and rumors last days of the movement.

As tension was mounting, one Afzal Hossain Raahim claimed in a Facebook post that the police arrested a college student at his home at Khilgaon.

\section{Afzal Hossain Raahim}

20 hrs

"আজ সকাল ৭ টায় শেখ রাইয়ান আহাম্মেদ আলিফ কে তার বাসা থেকে ধরে নিয়ে যায়। ধরে নিয়ে যাবার সময় নাকি পুলিশ এও বলেছে,

"বিচার চাইজেছছ না, চল বিচার করি"।

ছেলেটি খিলগাও গভমেন্ট কলোনী কলেজের HSC গ্র ২য় বর্ষের ছাত্র। বাসা কাজলা, যাত্রাবাড়ি।"

আমার আইনজীবী বন্ধু/ভাইবোনদের অনুরোধ করছি। বাচ্চাদের পাশে দাঁড়ান। ওরা একটঁ রাষ্ট্রব্যবস্থাকে মেরামত করতে রাজপথে নেমেছে। নামতে বাধ্য হয়েছে ওদের পাশে দাঁড়ান প্লিজ!

সাংবাদিক বন্ধুদেরও অনুরোধ করছি প্লিজ বাচ্চাটির খোঁজ নিন।
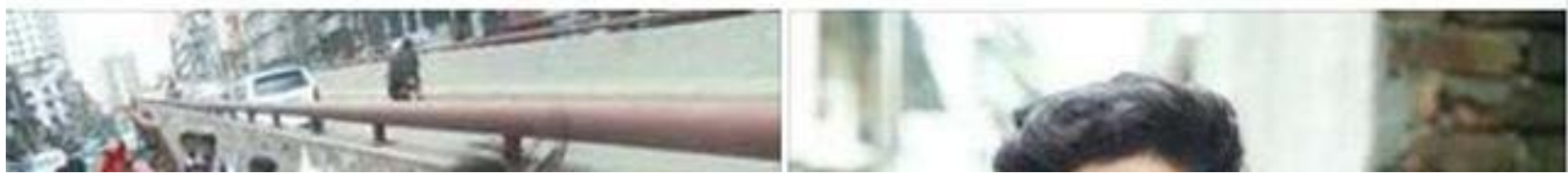

When the post went viral, the student himself had to write a post and confirmed that it was only a rumor. The falsely claimed arrested boy post on facebook, "Where do you get such fake news, and why are you embarrassing my family and me by posting these? This news is fake. Police haven't arrested me" (3 August 2018; bdnews24.com). Many people play a role in spreading rumors, and fake news as the tension of movement is high. 


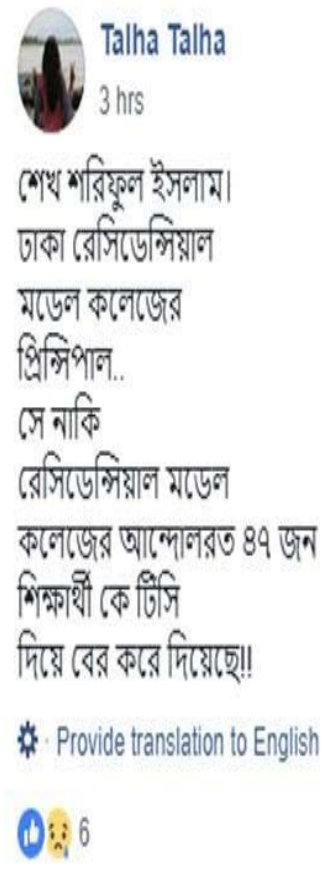

8.

others.

23 hrs : 9

apnara ulta palta news koi theka pan ar aisob news upload dia amake and amr family ke birokto korsen keno ar vai apnara sobai ao

I ai post share dia sobaike jania den aisob post ar na dite plz

aita pura fake ghotona!!

police amake dhorai nai!!

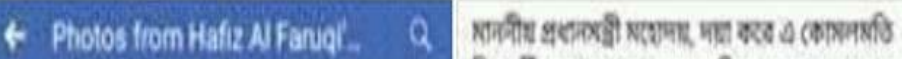

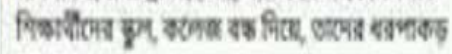
एक क्षमा

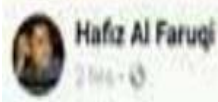

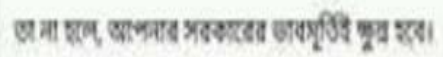

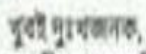

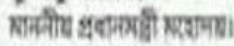

incident, two students were arrested in Dhaka for allegedly spreading rumors on social media during the recent student-led protests over road safety (16 August 2018; Dhaka Tribune). news, claiming it was 'baseless and misleading'. In this

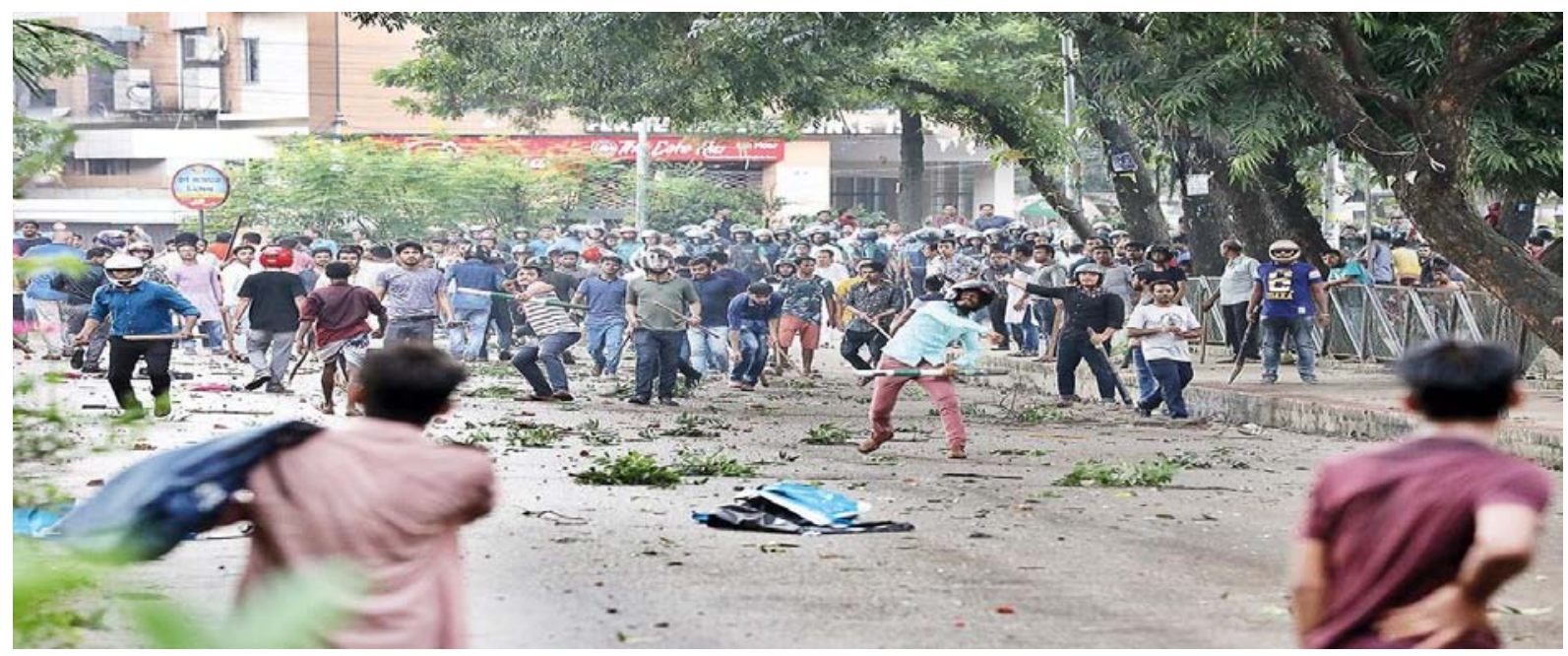

The violence of August $4^{\text {th }}$ in Dhaka's Jigatola was fueled by rumor-mongering, claims, and counter-claims on social media. Photo: Mehedi Hasan/Dhaka Tribune

The above-given picture went viral on Facebook that fuelled violence on movement. This violence-marred demonstrations on August 4 and 5 August Dhaka's Dhanmondi when police and ruling party affiliate organizations Chhatra League got involved and clashed with students, while swirling rumors, claims, and counter-claims on social media added fuel to the movement though it incident didn't happen. Another rumor fuelled violent ending of a student movement in early August led police to crackdown on several people. That's why till 11 August, DMP (Dhaka Metropolitan Police) and the CID (Criminal Investigative Department) arrested 97 people, mostly students of public and private universities, for spreading rumors on social media and instigating violence during the weeklong students movement for the safer road (Hasan: 2018).

Masud Hasan Chowdhury Shuvro uploaded a photo on his Facebook account during the recent road safety movement. The photo shows a policeman is charging batons on a female student demonstrator. But Dhaka Metropolitan Police (DMP) claimed the picture was taken on September 31, 2012, during a Power and Energy Ministry besiege program by National Committee to Protect Oil, Gas, Mineral Resources, 
Power and Ports. As a proof, the DMP portal also provided a snapshot of a news report containing the same photo published in a national daily on October 1 . In the later part of the safe road movement, false news of torturing students and raping female students at a ruling party's party office was spread through video posts (Alam; Daily Sun).

On 4 August 2018, Quazi Nawshaba Ahmad, actress and model, went live on Facebook and urged people to 'save the students from attacks' and claimed falsely that two students were killed. But she acknowledged that she hadn't seen anything with her "own eyes".

Her 1.37 minutes long live video went viral on Facebook, which made many aware citizens confused authors whether it was true or not. Later she was arrested by RAB (Rapid Action Battalion) accused of spreading rumor (4 August 2018; bdnews24.com).

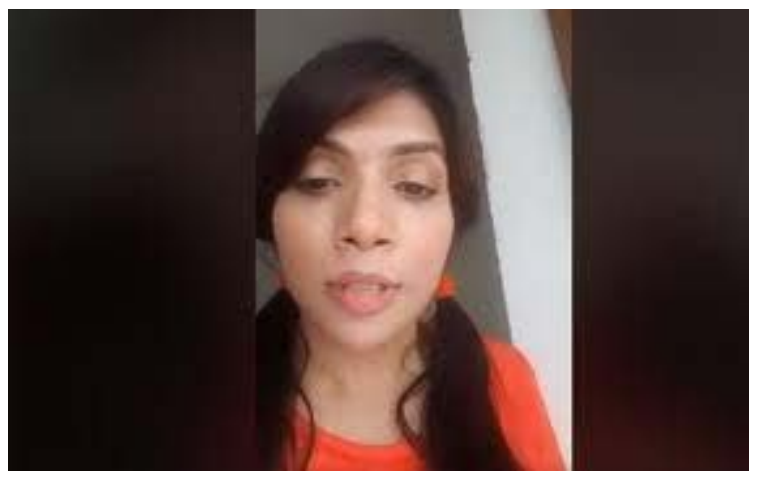

Nowshaba was on Facebook live.

Another live video went viral on Facebook. A Jigatala, Dhaka. This rumor can still be found now in the girl, covering her face, claimed that many school-going girls were being raped by rolling government affiliated Chhatra League activities at their party office situated at following link.

https://www.facebook.com/joydev.n/videos/2220475084 $863424 / ? \mathrm{t}=0$

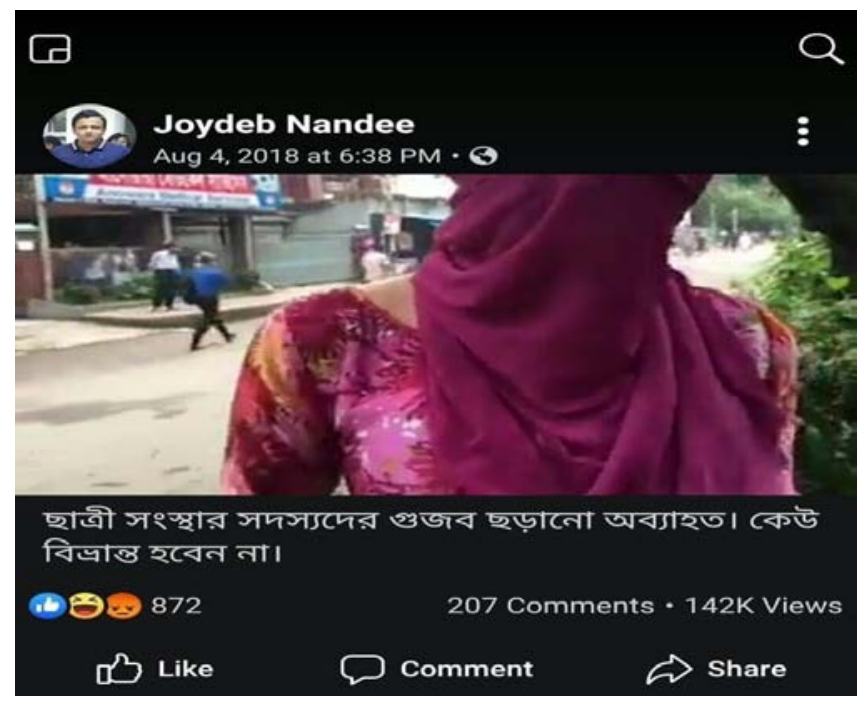

The following pictures also became viral on Facebook on 4 and 5 August 2018 which turned the road safety movement into violent. Though the person, M Mahbub Alam, who posted 'Is it rumor or Photoshop? We want a safe country...' including the picture on Facebook, is a teacher of a private university but confused by this violent picture. Many others become puzzled at this rumor, and took part to spread rumors unconsciously. 


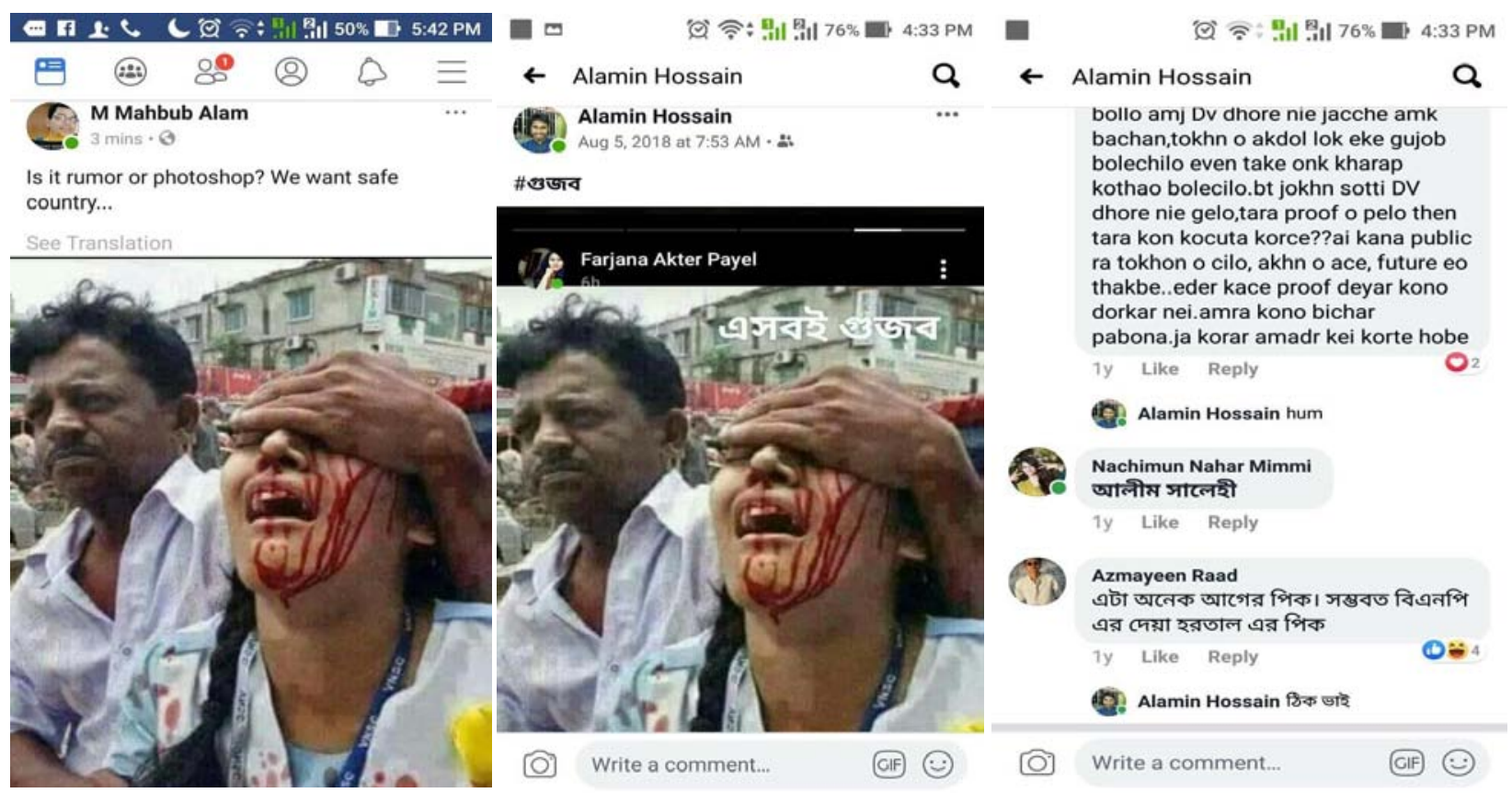

These pictures are collected as a snapshot from Facebook by the author 'Sharifa Umma Shirina'.

Not only Facebook users, but some baseless online portals contribute to spreading rumors by publishing fake news. Yousuf Chowdhury, chief executive officer (CEO) of online news portal 'Zoom Bangla' and two students from Dhaka and Bogra were arrested for allegedly trying to create anarchy by publishing fake news and spreading rumors on social media over the ongoing students' road safety movement (9 August 2018; Daily Star).

e) Religious hate speech and rumors spreading over Facebook led to mass death and vandalized.

Several mobs occurred in Bangladesh several times triggered by spreading religious hate speech, defamation, and rumors through the virtual realm, i.e., Facebook which resulted in death and vandalized.

The very fast rumor spread through Facebook draws the attention to Bangladesh in 2012 when using Faccbook was started in here. Since then Facebook has become a widely used tool for spreading rumors in Bangladesh. Hence, Bangladesh faces several crises of rumors frequently.

On 29 September 2012, a mob torched and vandalized several houses of Buddhists in Ramu, Cox's Bazar, one of the worst religious attacks in Bangladesh apparently triggered by a Facebook post allegedly defaming the Holly Quran of Muslims. A Buddhist temple in Ramu was burnt to the ground. The cause of this fanatic zealot was a local Buddist, Uttam Kumar Barua, being tagged in a Facebook image of burning Quran (29 September 2012; bdnews 24.com).

After Ramu violence, another fanatic mob vandalized at least 20 houses and shops run by local Hindus in the Bangram Bazar area of Ataikula, Pabna, in 2013. The incident stemmed from a rumor that Rajib
Saha made a post on Facebook, which demeaned the Prophet Muhammad (pbuh) (Rashid: 2019).

On 27 April 2014, fake news of defaming religious on Facebook caused to violence in Homna upazila of Comilla. At least 28 houses of Hindus were disrupted when the rumor of Prophet Muhammad (pbuh) had been defamed in Facebook by some Hindus. A rumor spread in the locality that two Hindu youths posted offensive on the social networking site Facebook about Prophet Muhammad (pbuh) which hurt Muslims. But the police have arrested 12 people for instigating violence and restoring to vandalism (29 April 2014: Daily Star).

On 30 October 2016, a violent mob attacked Hindu-dominated localities in Nasirnagar, Brahmanbaria, injuring more than 100 people and damaging at least 17 temples and over 50 houses due to an offensive Facebook post that hurts religious sentiments of Muslim. Six days later, mob attacked twice and set fire to houses of Hindus. The violence triggered by a Facebook post from the account named 'Rasraj Das,' son of Jagannath Das at Harinberh, Nasirnagar of Brahmabaria. Later, police arrested Rasraj Das for denigrating Islam and create chaos through social media and court ordered him into prison (Chakraborti: 2016).

The controversial Facebook post triggered the communal clash in Thakurpara, Rangpur on 10 November 2017. This clash causes one innocent killed and 20 wounded, including seven police officers. The rumor was that Titu Roy, originally from Thakurbari village but currently living in Narayanganj, put up a Facebook post defaming Prophet Muhammad (pbuh) a few days ago. This offensive post made villagers 
agitated and provoked to do heinous activities like they set fire at least 30 Hindu houses. Over 100 suspects were arrested in connection with the communal (Badal \& Hasan: 12 November 2017). A similar incident took place in very recent in Borhanuddin, Bhola, which is illustrated above. This is not enough; Bangladesh has faced similar several crises due to rumor in the past from when Facebook got popularity among mass people.

\section{Vil. Analysis and Discussion}

Bangladesh is continuously facing the acute problems of rumors spreading in the virtual realm like Facebook. The above-given documents show that almost every year, at least one serious social crisis has been created due to rumors spreading on Facebook in Bangladesh. Few dimensions can be traced regarding rumors based on the above evidence.

a. Most of the rumors spread during the crisis moments like movement. Perpetrators took the advantage of crisis moments. That's why during the 'Road Safety Movement' and 'Quota Reform Protests', several rumors spread on Facebook and went viral through the personal post and several Facebook pages.

b. Some evil-doers took the advantages of most used popular social media platform Facebook to incite fundamental religious sentiments to attack minorities in Bangladesh. Borhanudding clash in 2019, Thakurapara vandalism in 2017, Nasirnagar attack in 2016, and Ramu violence in 2012 are the notorious consequences of rumors spreading through Facebook. Perpetrators incite common people by defaming religious sentiments through posting on Facebook to create chaos in society. But most of the time, the evil-doers are successful in attaining their purpose as the above evidences say.

c. Offenders spread general prejudices on Facebook for creating violence when they get any opportunity. These prejudices are spread based on infrastructure development which few don't want. 'Rumor of child sacrifice for Padma Bridge' is one of the examples of such an incident.

d. Perpetrators choose social media platform Facebook to create violence in society to reach many people within a few minutes. There is no other medium as Facebook to become a post viral at supersonic speed.

e. Most of the rumors and fake news spread on online, e.i., Facebook but affected people offline. In all cases, the virtual realm's rumors resulted with consequence in real life. It can be said that the virtual realm shapes and controls our offline life or real life.

f. Another important thing to observe that rumors vary in terms of place and context and even level of education. Rumors regarding religious sentiments and prejudice spread in such a community and place where literacy rate is very low, mostly in villages.

g. Both educated and uneducated, but young generations are severely affected by rumors equally though the types of rumors are different. The above evidences show us this picture.

h. Most of the rumors are deliberately produced, and spread on Facebook and few repost or share intentionally but few others share unknowingly.

i. Rumors quickly turn into reality from the virtual realm and spread as soon as possible to gathers commoners.

j. Most of the Facebook users tend to believe in rumor rather than to verify its' authenticity.

k. Today's Facebook generation is suffering from a viral virus actually in the virtual realm. Some intent to be viral, and some contribute to do viral something. The over curiosity makes them like it. The young fabu-generation (facebook addicted generation) of Bangladesh has no interest in verifying any news or information. They always hurry to draw the attention of others by posting or reposting and sharing provocative news on Facebook. Very few have the patience to unveil the truth.

\section{Viil. Reasons for Spreading Rumors on The Virtual Realm}

Many reasons can be triggered the quickest spread of rumor in Bangladesh. There are uncountable numbers of online portals in Bangladesh. This rapid growth of online journalism is one of the major reasons for spreading rumors and fake news. Because most of the online portals are run by unskilled and less educated persons who have lack of news sense. Most of them have no ethical knowledge of journalism. A lack of a digital security act for controlling the web portal is another reason for spreading rumors and fake news. Because when a rumor is served covering as a news, whatever medium it doesn't matter,' people don't raise questions about its' authenticity. Though recently Digital Security Act has been adopted, its' implementation can't be seen yet. The lack of a digital security act paves the way for spreading fake news through the virtual realm. There are lots of laws and acts to punish criminals, but implementation is a rare case in the context of Bangladesh, which led people to uplift the law in their hand. Besides, people's mistrust of existing justice, mistrust of police, who are detached from mass people, are another reasons of violence in society. Political perpetrators deliberately spread rumors for taking revenge on political rivals and try to create a chaotic environment and derange social discipline to keep the ruling party in an awkward situation. The suspicious mind of mass people, lack of knowledge, and mass 
awareness are also considered as one of the major reasons for spreading fake news in Bangladesh. Lack of media literacy is one of the main reasons for spreading fake news and rumor in Bangladesh. Most of the people, who use social media platforms, don't know how to use and in what purpose. It may be the only one fake news but its' impacts on society is severe, which is figured out from above evidences.

\section{iX. Feasible Prevention}

Scientists and technologists have developed few websites and apps to check fake news, misinformation, and propaganda. Such as Glennkessler, PolitiFact, the Pulitzer Prize-winning fact-checker site, FackCheck.org (subjectguides.nscc.ca) are the popular fact checker by which fake news can be identified. BDFactCheck.com is now popular fact checker in Bangladesh. Alongside, suitable steps should be taken based on the above reasons to mitigate rumors and fake news as well. There is no other alternative way of education to prevent spreading rumors and to believe in rumors. Media literacy can minimize the gap between news and fake news and rumors. The fair implementation of the digital security act can reduce the rapid growth of web news portals, which are the main tools for spreading fake news sometimes and they practice copy-paste journalism and have no sense of ethics. As Facebook is the main tool for spreading rumors and fake news and is the reason of creating violence in the society, it should be monitored in such a creative way so that freedom of speech wouldn't be derogated. Besides, Facebook recently launched an artificial intelligence based program to predict and prevent suicides (wired.com). Similar programs can be implemented to predict and prevent violence and extremism by detecting suspicious users and activities from social networking platform Facebook. But the legal action is must and unavoidable step to throw cold water on rumors and fake news. The much-awaited 'Digital Security Act 2018' has been adopted to perish digital chaos in digital platforms and to make a more secure way of using social media. Though there is some debate about a few sections of the digital security act, it has made a legal way of protecting defaming, spreading fake news, fake information, and rumors on new media platform especially on Facebook. The Digital Security Act (2018) takes prevention measures and punishments under sections $8,28,29$ and 31 on hurting religious sentiment, and values, disrupting public order, dishing out defaming information and causing deterioration in law, and order by publishing anything on a website or in electronic form or digital format. On the contrary, this act under section 43 allows police in Bangladesh to search and arrest anyone if police official believes that an offense under the law has been or is being committed at a certain place, or there is a possibility of committing crimes or destroying evidence which is the most debatable section that shrinks the freedom of press and freedom of expression. A mass awareness can also be an effective step in preventing spreading rumor and fake news through the virtual realm. Besides, citizen must have to be aware of using Facebook and have use their own concise to differentiate between news and fake news and rumor before sharing.

\section{Conclusion}

Facebook has become a panic of spreading rumors and fake news in Bangladesh along with the world. The impact of spreading fake news in the virtual realm is severe, proved by the above evidence. Sometimes single fake news or rumor may cause to destruction of our secular entity in Bangladesh. It's high time to prevent spreading fake news and rumor on Facebook for our existence.

\section{References Références Referencias}

1. AFP, New Delhi. (2018, July 14). When fake news sparks violence India grapples with online rumours. Dhaka Tribune. Retrieved from https://www. dhakatribune.com/world/south-asia/2018/07/14/ when-fake-news-sparks-violence-india-grappleswith-online-rumours

2. AFP. (2019, July 25). Bangladesh eight lynched over false rumours of child sacrifice. The Guardian. Retrieved from https://www.theguardian.com/world/ 2019/jul/25/bangladesh-eight-lynched-over-falserumours-of-child-sacrifices

3. Alam, Mahabub. Facebook turns propaganda machine. Retrieved from https://www.dailysun.com/ amp/post/334068

4. Allcott, Hunt, and Matthew, Gentzkow (2017). Social Media and Fake News in The 2016 Election. Journal of Economic Perspectives 31 (2): 211-236.

5. Alexa.com. (2019, October 20). Top sites. Retrieved from https://www.alexa.com/topsites

6. Badal, Liakat Ali \& Hasan, Kamrul. (2017, November 12). Rangpur Attack: FB post uploaded from Rangpur, Titu lives in N'ganj. Dhaka Tribune. Retrieved from https://www.dhakatribune.com/ bangladesh/politics/2017/11/12/controversialfacebook-post-uploaded-from-rangpur/

7. Bangladesh Telecommunication Regulatory Commission (BTRC) (August 2019). Internet subscribers Bangladesh. Retrieved from http://www. btrc.gov.bd/content/internet-subscribersbangladesh-august-2019

8. Bdnews24.com. (2018, August 4). RAB arrests actress Nawshaba on charges of spreading rumours to incite violence. Retrieved from https:// bdnews24.com/bangladesh/2018/08/04/rab-arrestsactress-nawshaba-on-charges-of-spreadingrumours-to-incite-violence 
9. Bdnews24.com. (2018, August 3). Rumours swirl on facebook amid students protesters for safe roads. Retrieved from https://bdnews24.com/bangladesh/ 2018/08/03/rumours-swirl-on-facebook-amidstudent-protests-for-safe-roads

10. Bdnews24.com. (2012, September 29). Buddhist temples, homes burned, looted in Ramu. Retrieved from https://bdnews24.com/bangladesh/2012/09/ 29/buddhist-temples-homes-burned-looted-in-ramu

11. Cain, Patric. (2019, September 18). Fake news section of Elections Act faces Charter challenge. Global news. Retrieved from https://globalnews.ca/ news/5918877/fake-news-elections-act-free-speech/

12. Chakraborti, Ujjal. (2016, November 30). Nasirnagar communal attack: 3 police reports in a month, nothing on the motive. Dhaka Tribune. Retrieved from https://www.dhakatribune.com/bangladesh/ 2016/11/30/one-month-nasirnagar-communalviolence-police-yet-find-motive-behind-attacks

13. Connolly, Amanda. (2019, June 11). Canada: More than $60 \%$ of web users support governments censoring fake news: Ipsos poll. Global news. Retrieved from https://globalnews.ca/news/5376 867/how-to-fight-fake-news/

14. Daily Star. (2018, April 13). Quota Demo: Case over social media 'rumour', 200 FB accounts listed. Retrieved from https://www.thedailystar.net/topnews/case-over-social-media-rumour-200-fb-face book-accounts-listed-quota-demonstration-dhakauniversity-1562401

15. Daily Star. (2018, August 9). Spreading rumour: Online news portal official, 2 students detained. Retrieved from https://www.thedailystar.net/country /student-arrested-in-bogra-spreading-rumour-onsocial-media-over-student-protest-for-road-safetydemand-1618153

16. Daily Star. (2014, April 29). Hindu houses attacked on Facebook rumours. Retrieved from https://www. thedailystar.net/hindu-houses-attacked-on-face book-rumours-22087

17. Dhaka Tribune. (2018, August 16). Road safety movement: 2 students held over social media rumours. Retrieved from https://www.dhaka tribune.com/bangladesh/2018/08/16/road-safetymovement-2-students-held-over-social-mediarumours

18. Digital Security Act 2018. Retrieved from https:// www.cirt.gov.bd/wp-content/uploads/2018/12/ Digital-Security-Act-2018-English-version.pdf

19. Dustinstout.com. (2019, October 19). Social media statistics. Retrieved from https://dustinstout.com/ social-media-statistics/

20. Hasan, Kamrul. (2018, August 16). DMP: Some were instructed to spread rumours during road safety movement. Dhaka Tribune. Retrieved from https://www.dhakatribune.com/bangladesh/crime/ 2018/08/16/dmp-some-were-instructed-to-spreadrumours-during-road-safety-movement

21. Islam, Tariqul. (2019, February 01). Who shares fake news. Prothom Alo English. Retrieved from https:// en.prothomalo.com/opinion/news/190525/Whoshares-fake-news

22. Lahariya, Khabar. (2019, September 17). Killer rumour "They pluck outs hearts of children"-how fake news is crippling Indian villages with anxiety. qz.com. Retrieved from https://qz.com/india/1710 209/rural-india-in-turmoil-over-whatsapp-kidnapping -fake-news/

23. McLuhan, Marshall. (1964). Understanding Media. Retrieved from https://livinginternet.com/i/ii_ mcluhan.htm

24. Nagi, Kuldeep (2019). New Social Media and Impact of Fake News on Society. Indian Journal of Science and Technology. Doi: https://www. researchgate.net/publication/333775168.file://F:। Fake News ISSRN-id3258350.pdf.

25. Raju, Fazlur Rahman \& Shovon, Fahim Reza. (2018, April 17). How rumours and fake news shaped the quota reform protest. Dhaka Tribune. Retrieved from https://www.dhakatribune.com/opinion/special/2018 /04/17/rumours-fake-news-shaped-quota-reformprotest

26. Rashid, Mamunur. (2019, October 26). False Facebook posts killed 5 persons so far. observerbd.com. Retrieved from https://www. observerbd.com/details. php?id $=224919$

27. Roy; Prasanto K. (2019, October 30). Why India wants to track WhatsApp Messages. BBC. Retrieved from https://www.bbc.com/news/worldasia-india-50167569

28. Silverman, Craig. (2016, November 16). This Analysis Shows how Fake Election News Stories Outperformed Real News on Facebook. BuzzFeed News. Retrieved from https://www.buzzfeednews. com/article/craigsilverman/viral-fake-election-newsoutperformed-real-news-on-facebook

29. Silverman, Craig and Jeremy Singer-Vine. (2016, December 6). Most Americans Who See Fake News Believe It, New Survey Says. BuzzFeed News. Retrieved from https://www.buzzfeednews.com/ article/craigsilverman/fake-news-survey

30. Statista.com. (2019, October 19). Country based number of facebook users. Retrieved from https:// www.statista.com/statistics/268136/top-15-countries -based-on-number-of-facebook-users/

31. Shirin, Sharifa Umma. (2019, July 25). Excited Bangalis' believe in rumou. Kholakagoj. Retrieved from http://ekholakagoj.com/epaper/m/84874/ 5d389048a6ed1

32. Video of rumour. (2018). Retrieved from https:// www.facebook.com/joydev.n/videos/222047508486 $3424 / ? \mathrm{t}=0$ 
33. Wardle, Claire (2017). "Fake News. It's complicated". [Online]. Available: https://medium. com/1st-draft/fake-news-its-complicated-d0f7737 $66 c 79$

34. Worldometer.info. (2019, October 19). World population. Retrieved from https://www.worldo meters.info/world-population/

35. https://subjectguides.nscc.ca/FakeNews/FactChecking

36. https://www.bdfactcheck.com/ 